\title{
Short Communication: Polymorphism of myostatin gene and its association with body weight traits in a hybrid of GAMA chicken (Gallus gallus domesticus Linn. 1758)
}

\author{
ARDO TANJUNG ${ }^{1}$, H.T.S.S.G. SARAGIH ${ }^{2}$, TRIJOKO ${ }^{3}$, H.P. SOENARWAN ${ }^{3}$, S. WIDIANTO ${ }^{4}$, \\ I.W.S. MAHARDHIKA ${ }^{5}$, B.S. DARYONO ${ }^{5, \bullet}$ \\ ${ }^{1}$ Biology Graduate Program, Faculty of Biology, Faculty of Biology, Universitas Gadjah Mada. Jl. Teknika Selatan, Sleman 55281, Yogyakarta, \\ Indonesia \\ ${ }^{2}$ Laboratory of Animal Structure Development, Faculty of Biology, Universitas Gadjah Mada. Jl. Teknika Selatan, Sleman 55281, Yogyakarta, Indonesia \\ ${ }^{3}$ Laboratory of Animal Systematics, Faculty of Biology, Universitas Gadjah Mada. Jl. Teknika Selatan, Sleman 55281, Yogyakarta, Indonesia \\ ${ }^{4}$ Laboratory of Animal Physiology, Faculty of Biology, Universitas Gadjah Mada. Jl. Teknika Selatan, Sleman 55281, Yogyakarta, Indonesia \\ ${ }^{5}$ Gama Chicken Research Team, Laboratory of Genetics and Breeding, Faculty of Biology, Universitas Gadjah Mada. Jl. Teknika Selatan, Sekip Utara, \\ Sleman 55281, Yogyakarta, Indonesia. Tel./fax.:+62-274-580839, •email: bs_daryono@mail.ugm.ac.id, i.wayan.sm@mail.ugm.ac.id
}

Manuscript received: 8 July 2019. Revision accepted: 17 October 2019.

\begin{abstract}
Tanjung A, Saragih HTSSG, Trijoko, Soenarwan HP, Widianto S, Mahardhika IWS, Daryono BS. 2019. Polymorphism of myostatin gene and its association with body weight traits in a hybrid of GAMA chicken (Gallus gallus domesticus Linn. 1758). Biodiversitas 20: 3207-3212. An experiment was conducted to detect SNP of the myostatin gene and its association with the body weight of hybrid chicken crossbreed from $\mathrm{F}_{1}$ Kamper and $\mathrm{BC}_{1}$ Broiler. Four $\mathrm{F}_{1}$ Kamper hens were crossbred with $\mathrm{BC}_{1} \mathrm{Broiler}$ rooster. Day old chick (DOC) hatched were maintained for 49 days with body weight measurement every seven days. The blood samples from 49 days old chicken were taken for DNA isolation by Chelex 5\% method and then amplification of the myostatin gene. PCR products were sequenced, and sequence alignment was performed using Clustal Omega to obtain SNP. The SNP obtained was analyzed by the Pearson correlation test with the body weight of forty nine-days-old chickens. The body weight of the hybrid chicken is higher than of Pelung chicken but lower than the Broiler. There are 7 SNPs in myostatin gene exons included 2 Adenine insertions, 1 Guanine deletion, and four substitutions (C2244G, G2283A, T4842G, G7378T) that yield nine haplotypes. Six haplotypes had different protein sequences with Myostatin protein, while three haplotypes were identical to Myostatin protein. The correlation analysis showed that there was a strong positive correlation $(\mathrm{r}=0.736)$ between normal Myostatin protein and mutant to chicken body weight at 49-days-old. Adenine insertion to nucleotide $2099-2100$ of myostatin gene had a very strong positive correlation $(r=0.800)$ to 49 -days-old chicken body weight, although T4842G substitution had a strong negative relationship ( $\mathrm{r}=-0.773$ ) to 49-days-old chicken body weight. Adenine insertion to nucleotide 2099-2100 of myostatin gene could be a genetic marker of heavier body weight of the hybrid chicken.
\end{abstract}

Keywords: Adenine insertion, chicken body weight, genetic marker, myostatin gene, polymorphism

\section{INTRODUCTION}

Indigenous Indonesia chickens have to be maintained optimally to support small scale poultry industry Indigenous Indonesia chickens germplasm can be the solution for fulfilling the increasing demand for domestic food consumption (Daryono et al. 2010). Improvement of productivity and competitive quality of local broiler chicken can be achieved through selective breeding of indigenous Indonesia chicken breeds. Selective breeding is aimed to produce a superior chicken breed with adjusted phenotype quality according to human needs (Cheng 2010).

Pelung Blirik Hitam has several distinguished characters such as higher posture and body weight compared with other indigenous breeds (Daryono et al. 2010). Body weight of male Pelung chicken can reach 3.37 $\mathrm{kg}$, and females can reach $2.52 \mathrm{~kg}$ (Daryono et al. 2010). Hidayat and Asmarasari (2015) stated that in the period of 20 weeks body weight of Pelung can reach $1663 \mathrm{gram} / \mathrm{head}$ heavier than other meat producer indigenous chicken such as Kampung (1408 gram/head), Black Kedu (1480 gram/head), White Kedu (1320 gram/head) and Nunukan (1203 gram/head). Meanwhile, Broiler Cobb 500 has distinguished productivity and a high growth rate in the early phase ( 7 to 18 weeks). The male and female Broiler Cobb 500 can reach 1,599.17 grams and 1,540.46 grams (Hassan et al. 2016).

Indigenous chicken breed consists of 31 breeds which can be further classified into four functional groups i.e. singing chicken, used in traditional ceremonies, fancy and fighting cock, meat and egg producer (Hidayat and Asmarasari 2015). Selective breeding between Pelung Blirik Hitam and Broiler Cobb 500 produced hybrid chicken $\mathrm{F}_{1}$ Broiler or Kambro (Kampung-Broiler) (Mahardhika and Daryono 2019). Based on Body Weight (BT) measurement, Kambro population $(\mathrm{n}=17)$ with average $\mathrm{BT}$ of $1244.14 \pm 453.82$ grams was significant $(\mathrm{p}<.001)$ to $\mathrm{F}_{1}$ Pelung $(\mathrm{n}=7)$ with average BT of $602.88 \pm$ 79.93 grams in 8 weeks period with ad libitum diet of standard feed (Mahardhika and Daryono 2019). The improvement of Kambro performance was significant to $\mathrm{F}_{1}$ 
Pelung based on the measurement of linear body weight parameter, vitality parameter, $\mathrm{PPa}-\mathrm{PBe}$ parameter, and phenotype parameter (Mahardhika and Daryono 2019). Kambro has the phenotype combination of parental generation based on phenotype parameter (Hassan et al. 2016). In this study Backcross I of Broiler which derived from $\mathrm{F}_{1}$ Broiler ( + Broiler $\mathrm{x} \precsim \widehat{\jmath}$ Pelung) crossbreed with its Pelung male parent was used. This $\mathrm{BC}_{1}$ Broiler has higher growth than local Indonesian chicken and more uniform character than the $F_{1}$ Broiler (Utama et al. 2018). Both chickens can be used to be parental for selective breeding methods. This method required morphological and molecular character that can be used as a marker.

Accompanying selection for rapid growth, meat-type chickens exhibit an increase in physiological disorders such as obesity, multitrait selection to simultaneously improve fitness and increase production is, therefore, difficult to achieve by direct selection. Molecular marker-assisted selection (MAS) may be required, and the integration of traditional genetic selection and modern molecular methods may be preferred for breeding chickens in the future. Advances in molecular biotechnology enable fast and reliable methods for the accurate diagnosis of mutations responsible for different genetic defects.

Myostatin gene, also called Growth and Differentiation Factor 8 (GDF-8) belonging to TGF- $\beta$ superfamily, has the function of regulating the growth and differentiation of skeletal muscle (Sharma et al. 2015). There is 44 known polymorphism in the myostatin gene. Some of them are associated with growth (Bhattacharya and Chatterjee 2013; Dushyanth et al. 2016). Therefore, this study aimed to detect myostatin gene polymorphism in hybrid chicken and its association to body weight so that it can be used as a genetic marker to determine the best individual to become a parent stock.

\section{MATERIALS AND METHODS}

\section{Chicken breeding}

Chicken used in this study were Day Old Chick (DOC) crossbreed of $q \mathrm{~F}_{1}$ Kamper and $\widehat{\supset} \mathrm{BC}_{1}$ Broiler (Figure 1), DOC of Broiler as positive control and DOC of Pelung as the negative control. The DOC was maintained for 49 days with lighting 24 hours using 10 watts light bulb, air temperature $\pm 30^{\circ} \mathrm{C}$ and $40-50 \%$ humidity, feed by BR I (Japfa Comfeed) ad libitum and body weight measurement every seven days. $1 \mathrm{~mL}$ of blood was taken from 49-daysold chicken samples from wings vein using $26 \mathrm{G}$ syringe and stored in an EDTA tube and at $-20^{\circ} \mathrm{C}$ until used for DNA isolation.

\section{DNA isolation}

The DNA isolation protocol performed was the Chelex method (Butler 2016) with modified concentration of Chelex concentration according to optimization phase. A total of $10 \mu \mathrm{L}$ of blood samples were mixed into a $1 \mathrm{~mL} \mathrm{TE}$
$10 \mathrm{mM} \mathrm{pH} 8$ in $1.5 \mathrm{~mL}$ Eppendorf tube and then centrifuged at $13,000 \mathrm{rpm}$ for $3 \mathrm{~min}$. The centrifugation supernatant was discarded and $200 \mu \mathrm{L}$ Chelex 5\%, $18 \mu \mathrm{L}$ DTT $0.01 \mathrm{M}$, and $2 \mu \mathrm{L}$ Proteinase $\mathrm{K} 10 \mathrm{mg} / \mathrm{mL}$ were added. The mixture was incubated at $56^{\circ} \mathrm{C}$ for 1 hour with vortex every $15 \mathrm{~min}$. Then incubated in $100^{\circ} \mathrm{C}$ for $8 \mathrm{~min}$ and centrifuged at 13,000 rpm for $3 \mathrm{~min}$. The supernatant containing DNA isolate $( \pm 150 \mu \mathrm{L})$ was transferred to a new Eppendorf tube for storage at $-20^{\circ} \mathrm{C}$ until used as a PCR template.

\section{Polymerase Chain Reaction (PCR)}

Polymerase Chain Reaction was done using the master mix MyTaq HS Red Mix of Bioline. Primer was used to amplify the myostatin gene fragment are listed in Table 1. The mixtures added into each PCR tube were $25 \mu \mathrm{L}$ PCR master mix, $2.5 \mu \mathrm{L}$ forward primer $(10 \mathrm{pM} / \mu \mathrm{L})$ and $2.5 \mu \mathrm{L}$ reverse primer $(10 \mathrm{pM} / \mu \mathrm{L}), 10 \mu \mathrm{L}$ DNA template $(10$

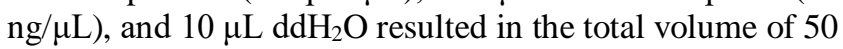
$\mu \mathrm{L}$.

The PCR reaction consisted of predenaturation $95^{\circ} \mathrm{C}$ for $1 \mathrm{~min}$, followed by 35 cycles of denaturation $95^{\circ} \mathrm{C}$ for 15 sec, annealing $55^{\circ} \mathrm{C}$ for $15 \mathrm{sec}$, and elongation $72^{\circ} \mathrm{C}$ for 10 sec and the final elongation $72^{\circ} \mathrm{C}$ for $5 \mathrm{~min}$. The PCR product was visualized on $2 \%$ agarose gel electrophoresis. The generated amplicons were separated by agarose gel and visualized under UV light by AnalytikJena ${ }^{\mathrm{TM}}$ gel imaging system and documented with GelDoc ${ }^{\text {TM }}$ Documentation System. The mutant allele and wild-type allele are differentiated by checking the amplicon sizes in reference to size markers. Images of electrophoresis gel were analyzed with ImageLab (V. 6.0.1) to identify normal and mutant bands based on base-pair length with BenchTop $100 \mathrm{bp}$ ladder. Agarose gel was added with $3 \mu \mathrm{L}$ FloroSafe DNA Stain 1st Base for each running with $4 \mu \mathrm{L}$ PCR sample and $4 \mu \mathrm{L} 100$ bp ladder. Electrophoresis was performed with electroporator Mupid-exUTM, and TAE Buffer 0,5X was used as a buffer solution.

\section{Sequencing}

The PCR product was sequenced by Sanger sequencing method in $1^{\text {st }}$ Base Company, Selangor, Malaysia.

Table 1. Myostatin gene primer was used (Perdamaian et al. 2017)

\begin{tabular}{|c|c|c|}
\hline $\begin{array}{l}\text { Primer } \\
\text { name* }\end{array}$ & Primer Sequence (5'-3') & Fragment $\begin{array}{l}\text { Size } \\
\text { (bp) }\end{array}$ \\
\hline
\end{tabular}

MYTmF ATGCAAAAGCTAGCAGTCTATG Exon 1373

MYTE1R ACTCCGTAGGCATTGTGATAAT

MYTE2F CTGATTTTCTTGTACAAATGGAG Exon 2374

MYTE2R CAATCCATCTTCACCCGGTC

MYTE3F AACCCATTTTTAGAGGTCAGAG Exon 3381

MYTmR TCATGAGCACCCGCAACGAT

Note: *F: Forward primer; R: Reverse primer 


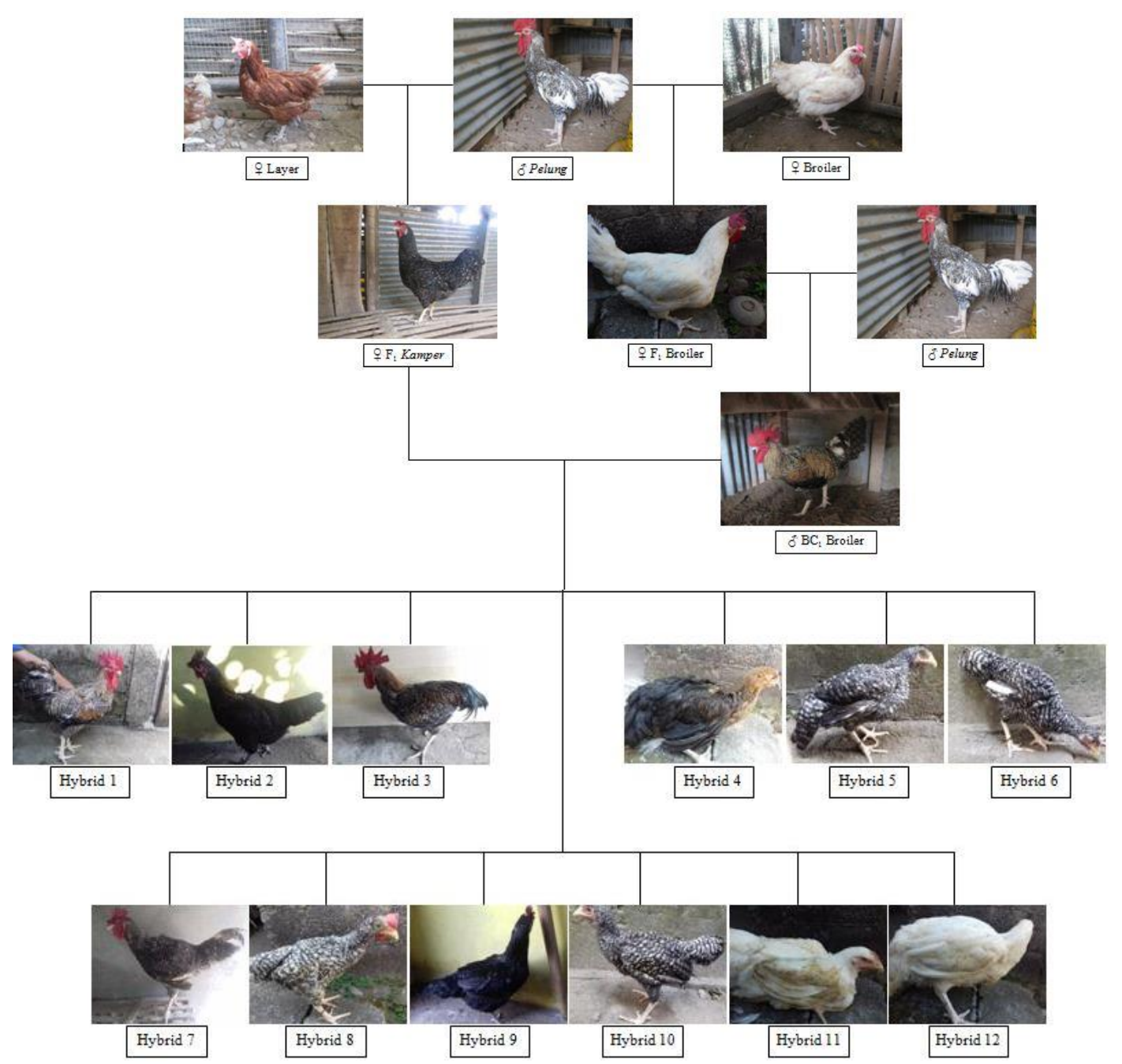

Figure 1. Pedigree of hybrid chicken from crossbreed $\mathrm{F}_{1}$ Kamper and $\mathrm{BC}_{1}$ Broiler

\section{Data analysis}

The data obtained were DOC body weight 0d-49d (Table 2) and was analyzed using ANOVA $(\mathrm{p}<0.05)$ statistical test and post hoc LSD method (reference ?) to assess the significance between chicken strains. The hybrid chicken was separated by sex ( 6 males and six females) for weighing by using digital scale @KrisChef. Myostatin gene sequencing result was processed using Gene Studio software, multiple sequences alignment between individuals using Clustal Omega software, and SNP association with chicken weight by using Pearson correlation test (Arnedo et al. 2007) in SPSS software. The polymorphisms obtained in this study lies in the coding region, so it is necessary to predict the amino acid changes using Sequence Translation Sites software online. The results of each haplotype translation then made alignment using Clustal Omega software to observe differences in protein arrangement between haplotype.

\section{RESULTS AND DISCUSSION}

\section{Chicken growth}

The purpose of the formation of this new chicken strain in addition to having a phenotype character as a local chicken also has faster growth than local chicken so it can be harvested more quickly to increase the production of domestic chicken meat. In this study, we used ${ }^{\Uparrow}$ Backcross I Broiler, which is the offspring of pure line broiler to increase the rate of growth of hybrid chick. In addition, the purpose of $\mathrm{F}_{1}$ Kamper use is to inherit the laying traits obtained from the Layer parent (Figure 1).

The hybrid chicken has higher growth rate compared to Pelung chicken, but has lower growth rate when compared to Broiler chicken (Table 2). ANOVA test results indicated a significant weight difference between the three types of chickens. The growth of hybrid chicken that lies between the growth line of Pelung and Broiler chicken due to the hybrid chicken has a lineage of both. Hence, it is important to further investigate the cause of differences in the growth of these chickens, by assessing myostatin gene polymorphism that has been known to be one of the genetic markers for chicken growth. 
Table 2. Hybrid, Pelung, and Broiler chicken body weight 0-49 days

\begin{tabular}{|c|c|c|c|c|c|c|c|}
\hline \multirow{2}{*}{ Chicken line } & \multicolumn{7}{|c|}{ Days-old } \\
\hline & 7 & 14 & 21 & 28 & 35 & 42 & 49 \\
\hline Hybrid [n=12] & $66.83 \pm 8.419^{b}$ & $125.00 \pm 15.892^{b}$ & $184.17 \pm 25.778^{b}$ & $268.08 \pm 50.581^{b}$ & $350.75 \pm 81.114^{\mathrm{b}}$ & $435.58 \pm 88.584^{b}$ & $529.92 \pm 117.586^{b}$ \\
\hline Pelung $[\mathrm{n}=5]$ & $33.60 \pm 3.507^{\mathrm{a}}$ & $45.20 \pm 8.871^{\mathrm{a}}$ & $62.80 \pm 19.267^{\mathrm{a}}$ & $95.80 \pm 26.205^{\mathrm{a}}$ & $143.00 \pm 37.703^{\mathrm{a}}$ & $196.60 \pm 33.568^{a}$ & $289.40 \pm 56.871^{\mathrm{a}}$ \\
\hline Broiler $[n=6]$ & $194.00^{c}$ & $461.00^{c}$ & $842.00^{c}$ & $1309.00^{c}$ & $1817.00^{c}$ & $2347.00^{c}$ & $2897.00^{c}$ \\
\hline
\end{tabular}

Table 3. SNPs of myostatin gene

\begin{tabular}{|c|c|c|c|c|c|c|c|c|}
\hline \multirow{3}{*}{ Sample } & \multicolumn{7}{|c|}{ Position in the myostatin gene } & \multirow{3}{*}{ Haplotype } \\
\hline & \multicolumn{5}{|c|}{ Exon 1} & \multirow{2}{*}{$\begin{array}{c}\text { Exon 2 } \\
\text { T4842G } \\
\text { substitution }\end{array}$} & \multirow{2}{*}{$\begin{array}{c}\text { Exon 3 } \\
\text { G7378T } \\
\text { substitution }\end{array}$} & \\
\hline & $\begin{array}{c}2099-2100 \\
\text { A insertion }\end{array}$ & $\begin{array}{c}2108-2109 \\
\text { A insertion }\end{array}$ & $\begin{array}{c}2109 \\
\text { G deletion } \\
\end{array}$ & $\begin{array}{c}\text { C2244G } \\
\text { substitution }\end{array}$ & $\begin{array}{c}\text { G2283A } \\
\text { Substitution }\end{array}$ & & & \\
\hline AF346599 & - & - & $\mathrm{g}$ & $\mathrm{c}$ & $\mathrm{g}$ & $\mathrm{t}$ & $\mathrm{g}$ & Reference \\
\hline Hybrid 1 & $\mathrm{a}$ & - & $\mathrm{g}$ & $\mathrm{c}$ & $\mathrm{a}$ & $\mathrm{k}$ & $\mathrm{g}$ & 1 \\
\hline Hybrid 2 & - & a & $\mathrm{g}$ & $\mathrm{s}$ & a & $\mathrm{k}$ & $\mathrm{g}$ & 2 \\
\hline Hybrid 3 & $\mathrm{a}$ & - & $\mathrm{g}$ & $\mathrm{c}$ & a & $\mathrm{k}$ & $\mathrm{g}$ & 1 \\
\hline Hybrid 4 & - & $\mathrm{a}$ & $\mathrm{g}$ & $\mathrm{s}$ & $\mathrm{a}$ & $\mathrm{g}$ & $\mathrm{g}$ & 3 \\
\hline Hybrid 5 & $\mathrm{a}$ & - & $\mathrm{g}$ & $\mathrm{c}$ & $\mathrm{r}$ & $\mathrm{k}$ & $\mathrm{g}$ & 4 \\
\hline Hybrid 6 & - & a & $\mathrm{g}$ & $\mathrm{s}$ & $\mathrm{r}$ & $\mathrm{k}$ & $\mathrm{g}$ & 5 \\
\hline Hybrid 7 & $\mathrm{a}$ & - & $\mathrm{g}$ & $\mathrm{c}$ & $\mathrm{a}$ & $\mathrm{k}$ & $\mathrm{g}$ & 1 \\
\hline Hybrid 8 & - & - & $\mathrm{g}$ & $\mathrm{c}$ & r & $\mathrm{g}$ & $\mathrm{g}$ & 6 \\
\hline Hybrid 9 & - & $\mathrm{a}$ & $\mathrm{g}$ & $\mathrm{s}$ & $\mathrm{a}$ & $\mathrm{k}$ & $\mathrm{g}$ & 2 \\
\hline Hybrid 10 & $\mathrm{a}$ & - & $\mathrm{g}$ & $\mathrm{c}$ & $\mathrm{a}$ & $\mathrm{k}$ & $\mathrm{g}$ & 1 \\
\hline Pelung 1 & - & $\mathrm{a}$ & $\mathrm{g}$ & $\mathrm{s}$ & $\mathrm{a}$ & $\mathrm{k}$ & $\mathrm{k}$ & 7 \\
\hline Pelung 2 & - & $\mathrm{a}$ & - & $\mathrm{g}$ & $\mathrm{a}$ & $\mathrm{k}$ & $\mathrm{k}$ & 8 \\
\hline Pelung 3 & - & $\mathrm{a}$ & - & $\mathrm{g}$ & $\mathrm{a}$ & $\mathrm{g}$ & $\mathrm{g}$ & 9 \\
\hline Pelung 4 & - & $\mathrm{a}$ & $\mathrm{g}$ & $\mathrm{s}$ & $\mathrm{a}$ & $\mathrm{g}$ & $\mathrm{g}$ & 3 \\
\hline Pelung 5 & - & $\mathrm{a}$ & - & $\mathrm{g}$ & $\mathrm{a}$ & $\mathrm{g}$ & $\mathrm{g}$ & 9 \\
\hline
\end{tabular}

Note: *a: adenine; g: guanine; c: cytosine; t: thymine; s: guanine or cytosine; r: adenine or guanine; k: guanine or thymine

\section{Myostatin gene polymorphism}

Myostatin gene polymorphism has been known to associate with the growth of chicken weight (Zhang et al. 2011). The SNPs obtained in this study (Table 3) were based on previous research by Bhattacharya and Chatterjee (2013). There are 7 SNPs, i.e. 2 Adenine insertions (20992100 and 2108-2109), 1 Guanine deletion (2109), and four substitutions (C2244G, G2283A, T4842G, G7378T) on the three exons of the myostatin gene. Two of the SNP obtained were the substitution of G2283A also obtained in Bian chickens which is the indigenous chicken from China and substitution of T4842G also obtained in Kampung, Merawang, and Sentul chicken which are the indigenous chicken of Indonesia (Zhang et al. 2011; Zhang et al. 2012; Khaerunnisa et al. 2016). Several SNPs in the myostatin gene such as C7552T, C7638T, and T7661 A has existed in noncoding exon 3 (Zhang et al. 2011). Some SNPs have found in the 5 ' regulatory region, and the exon 1 myostatin gene is A326G, C334G, G673A, G985C, G1085A, A1278T, C1346T, G1375A, A1473G, G1491A, and G2283A (Zhang et al. 2012; Zhang et al. 2012). In addition, some of the polymorphisms that have been obtained in myostatin genes in chickens include G167A, T177C, G304A, A322G, and C334T in regulator region 5' and $\mathrm{A} 6935 \mathrm{G}$ and $\mathrm{A} 7263 \mathrm{~T}$ in the 3 ' regulatory region (Gu et al. 2002).
These seven SNPs from nine haplotypes. The result of protein alignment (Figure 2) suggested there were differences in the protein arrangement between haplotype resulting from polymorphism. There are two protein patterns of nine haplotypes based on Genbank reference. The first type that is is identical to the GenBank reference were haplotype 6, 8, and 9 predominantly found in Pelung chicken. The second type that was different from GenBank reference where haplotype $1,2,3,4,5$, and 7 possessed by hybrid chicken. The difference of protein arrangement in hybrid chickens is caused by insertion mutation between nucleotides to 2099-2100 and nucleotides to 2108-2109, so there is a frameshift mutation of codon that resulted in changing of protein arrangement after mutation point. Frameshift mutation often leads to changes in protein structures resulting in protein malfunctions or protein degradation that should be formed. This is consistent with the theory that myostatin gene mutations cause an increase in weight due to Myostatin protein degradation, so that myoblast proliferation occurs continuously ( $\mathrm{Ye}$ et al. 2006). The mutations that have been obtained in the coding region are the mutations in the coding region of exon 1 G2283A acquired but do not cause changes in amino acids (silent mutation) (Zhang et al. 2011). Changes in the composition of these amino acids cannot be known whether the phenotypic changes that occur, so it needs to be further investigated. 

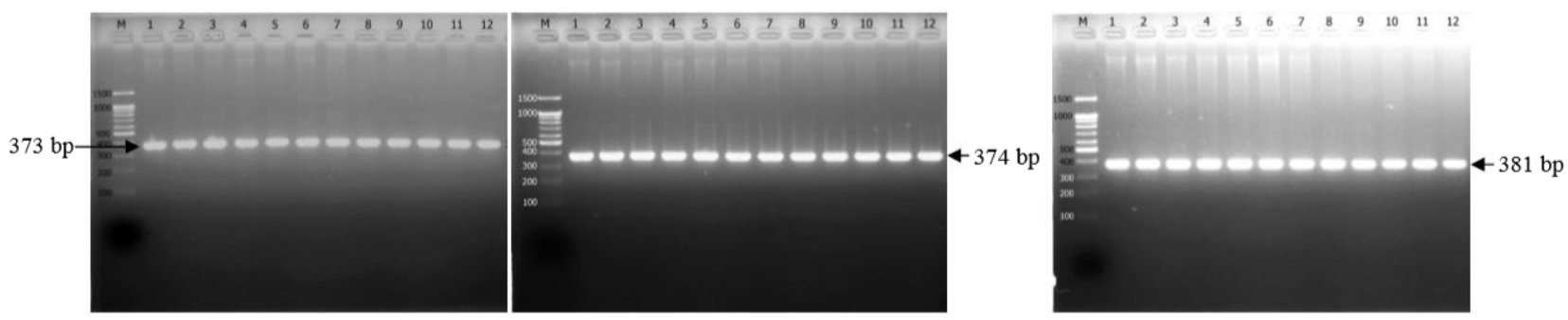

Figure 2. Myostatin gene visualization results (A) exon 1 (373 bp); (B) exon 2 (374 bp); (C) exon 3 (381 bp); M: DNA ladder 100 bp; 1-12: sample code of hybrid chickens (arrows indicate size of amplified fragments)

Table 4. Correlation test myostatin polymorphism to chicken weight at 49 days-old

\begin{tabular}{|c|c|c|c|c|c|c|c|c|c|c|c|c|c|}
\hline \multirow{2}{*}{$\begin{array}{l}\text { Polymorphism } \\
\text { Genotype }\end{array}$} & \multicolumn{2}{|c|}{$\begin{array}{c}\text { Insertion-A } \\
2099-2100 \\
\end{array}$} & \multicolumn{2}{|c|}{$\begin{array}{c}\text { Insertion-A } \\
2108-2109 \\
\end{array}$} & \multicolumn{3}{|c|}{ Subtitution-C2244G } & \multicolumn{3}{|c|}{ Subtitution-C2283A } & \multicolumn{3}{|c|}{ Subtitution-T4842G } \\
\hline & - & AA & - & AA & $\mathrm{CC}$ & $\mathrm{CG}$ & GG & $\overline{G G}$ & GA & $\overline{\mathrm{AA}}$ & TT & TG & GG \\
\hline Frequency of genotype & 0.5 & 0.5 & 0.6 & 0.4 & 0.6 & 0.4 & 0 & 0 & 0.3 & 0.7 & 0 & 0.8 & 0.2 \\
\hline $\begin{array}{l}\text { Average of chicken body } \\
\text { weight on 49th-day (g) }\end{array}$ & 473.4 & 640.2 & 595.7 & 498.5 & 595.7 & 498.5 & - & - & 503.3 & 579.7 & - & 579.1 & 395.5 \\
\hline Correlation coefficient & \multicolumn{2}{|c|}{0.800} & \multicolumn{2}{|c|}{-0.457} & \multicolumn{3}{|c|}{-0.457} & \multicolumn{3}{|c|}{0.336} & \multicolumn{3}{|c|}{-0.773} \\
\hline Significance & \multicolumn{2}{|c|}{$\begin{array}{l}0.005 * * \\
(\mathrm{p}<0.01)\end{array}$} & \multicolumn{2}{|c|}{$\begin{array}{c}0.185 \\
(p>0.05)\end{array}$} & \multicolumn{3}{|c|}{$\begin{array}{c}0.185 \\
(\mathrm{p}>0.05)\end{array}$} & \multicolumn{3}{|c|}{$\begin{array}{c}0.343 \\
(\mathrm{p}>0.05)\end{array}$} & \multicolumn{3}{|c|}{$\begin{array}{l}0.009 * * \\
(\mathrm{p}<0.01)\end{array}$} \\
\hline Finding & \multicolumn{2}{|c|}{$\begin{array}{l}\text { Significant; very } \\
\text { strong positive } \\
\text { correlation }\end{array}$} & \multicolumn{2}{|c|}{$\begin{array}{l}\text { Not significant; } \\
\text { negatively } \\
\text { correlated }\end{array}$} & \multicolumn{3}{|c|}{$\begin{array}{l}\text { Not significant; } \\
\text { negatively correlated }\end{array}$} & \multicolumn{3}{|c|}{$\begin{array}{l}\text { Not significant; } \\
\text { positively correlated }\end{array}$} & \multicolumn{3}{|c|}{$\begin{array}{l}\text { Significant; strong } \\
\text { negative correlation }\end{array}$} \\
\hline
\end{tabular}

Mutations in the myostatin gene were first observed in mice treated with knockout myostatin gene expression of hyperplasia and skeletal muscle fibers hypertrophy, resulting in a doubling of the mice's weight compared to normal. The double-muscling events are also found in Belgian Blue and Piedmontese cattle that have mutations in the coding region of myostatin gene (Kambadur et al. 1997; McPherron and Lee 1997; Wiener et al. 2009). Mutation of the myostatin gene was also found in sheep and goat. Mutation in sheep myostatin associated with doublemuscling and birth weight (Gan et al. 2008; Farhadian et al. 2012). While in goat, myostatin gene polymorphism associated with growth traits (Alakilli et al. 2012). Furthermore, the myostatin gene not only regulates skeletal muscle development but also plays a role in metabolism and fat deposition in chicken (Gu et al. 2003).

\section{Association of polymorphism with growth traits}

Changes in protein structure due to expressed polymorphism can be observed by analyzing the difference of chicken body weight with Pearson correlation test (Arnedo et al. 2007). Haplotypes having identical protein arrangements to GenBank references are considered normal phenotypes whereas haplotypes having different protein arrangements with GenBank references are considered mutant phenotypes. Both of these phenotypes performed a correlation test on the weight of chickens on 49-day-old using Pearson correlation test. The results from Pearson correlation test suggested that there is a strong positive correlation $(r=0.736)$ and significant between the normal phenotype and the mutant against the 49-days-old chicken weight (Table 4). This suggests that there is an increase in chicken weight due to the myostatin gene polymorphism.

\section{ACKNOWLEDGEMENTS}

This research was funded by the Ministry of Higher Education Republic of Indonesia (Kemenristekdikti) through Applied Research (Penelitian Terapan) Funding scheme PT 2019: No. 2830/UN1.DITLIT/DITLIT/LT/2019. Authors also would like to express the gratitude to Gama Ayam Research Team, Mr. Suryadi, and Pusat Inovasi Agroteknologi (PIAT) UGM for their kind assistance during this research work.

\section{REFERENCES}

Alakilli SYM, Mahrous KF, Salem LM, Ahmed ES. 2012. Genetic polymorphism of five genes associated with growth traits in goat. Afr J Biotechnol 11 (82): 14738-48.

Arnedo M, Taffé P, Sahli R, Furrer H, Hirschel B, Elzi L, Weber R, Vernazza P, Bernasconi E, Darioli R, Bergmann S, Beckmann JS, Telenti A, Tarr PE. 2007. Contribution of 20 single nucleotide polymorphisms of 13 genes to dyslipidemia associated with antiretroviral therapy. Pharmacogenet Genom 17: 755-764.

Bhattacharya TK, Chatterjee RN. 2013. Polymorphism of the myostatin gene and its association with growth traits in chicken. Poult Sci 92: 910-915.

Butler JM. 2009. DNA extraction from forensic samples using Chelex. Cold Spring Harbor Protocols 4 (6). DOI: 10.1101/pdb.prot5229.

Cheng HW. 2010. Breeding of tomorrow's chickens to improve wellbeing. Poult Sci 89: 805-813

Daryono BS, Roosdianto I, Saragih HTS. 2010. Pewarisan karakter fenotip ayam hasil persilangan ayam pelung dengan ayam cemani. J Veteriner 11 (4): 257-263. [Indonesian]

Dushyanth K, Bhattacharya TK, Shukla R, Chatterjee RN, Sitaramamma T, Paswan C, Guru-Vishnu P. 2016. Gene Expression and Polymorphism of myostatin gene and its association with growth traits in chicken. Anim Biotechnol 27: 269-277

Farhadian M, Hashemi A, Mardani K, Darvishzadeh R, Jafari, S. 2012. Polymorphisms in the ovine myostatin gene are associated with birth 
weight but not with weight gain in Iranian Makoei sheep. Genet Mol Res 11 (4): 3568-75.

Gan SQ, Du Z, Liu SR, Yang YL, Shen M, Wang XH, Yin JL, Hu XX, Fei J, Fan JJ, Wang JH, He QH, Zhang YS, Li N. 2008. Association of SNP haplotypes at the myostatin gene with muscular hypertrophy in sheep. Asian-Aust J Anim Sci 21 (7): 928-935.

Gu ZL, Zhang HF, Zhu DH, Li H. 2002. Single nucleotide polymorphism analysis of the chicken myostatin gene in different chicken lines. $\mathrm{Yi}$ Chuan Xue Bao 29: 565-570.

Gu ZL, Zhu DH, Li N, Li H, Deng XM, Wu CX. 2003. Polymorphism of myostatin gene and its relationship with the development of skeletal muscle and fat in chickens. Sci China C Life Sci 33: 273-80.

Hassan KMd, Kabir HMd, Sultana S, Hossen AMD, Haq MM. 2016. Management and production performance of Cobb-500 broiler parent stock under open housing system. Asian Australas J Biosci Biotechnol 1 (1): 66-72.

Hidayat $\mathrm{C}$ and Asmarasari SA. 2015. Native chicken production in indonesia: a review. Jurnal Peternakan Indonesia 17 (1): 1-11. [Indonesian]

Kambadur R, Sharma M, Smith TPL, Bass JJ. 1997. Mutations in myostatin (GDF8) in double-muscled Belgian Blue and Piemontese cattle. Genome Res 7: 910-6.

Khaerunnisa I, Pramujo M, Arief II, Budiman C. 2016. Polymorphism of the $\mathrm{T} 4842 \mathrm{G}$ myostatin gene is associated with carcass characteristics in Indonesian chicken. Intl J Poult Sci 15 (8): 316-24.

Mahardhika IWS, Daryono BS. 2019. Phenotypic performance of Kambro crossbreeds of + Broiler Cobb 500 and $\delta$ Pelung Blirik Hitam. Buletin Veteriner Udayana 11 (2): 188-202.

McPherron AC, Lee SJ. 1997. Double muscling in cattle due to mutations in the myostatin gene. Proc Natl Acad Sci USA 94: 12457-12461.
Perdamaian ABI, Saragih HTSSG, Daryono BS. 2017. Effect of varying level of crude protein and energy on insulin-like growth Factor-I expression level in Indonesian hybrid chicken. Intl J Poult Sci 16 (1): $1-5$

Sharma M, McFarlane C, Kambadur R, Kukreti H, Bonala S, Srinivasan S. 2015. Myostatin: Expanding horizons. IUBMB Life 67: 589-600.

Utama IV, Perdamaian ABI, Daryono BS. 2018. Plumage uniformity, growth rate, and growth hormone polymorphism in Indonesian hybrid chickens. Intl J Poult Sci 17: 486-492.

Wiener P, Woolliams JA, Frank-Lawale A, Ryan M, Richardson RI, Nute GR, Wood JD, Homer D, Williams JL. 2009. The effects of a mutation in the myostatin gene on meat and carcass quality. Meat Sci 83: $127-134$

Ye X, Brown SR, Nones K, Coutinho LL, Dekkers JCM, Lamont SJ. 2006. Associations of myostatin gene polymorphisms with performance and mortality traits in broiler chickens. Genet Sel Evol 39: 73-89.

Zhang G, Dai G, Wang J, Wei Y, Ding F, Li Z, Zhao X, Xie K, Wang W. 2012. Polymorphisms in 5'-upstream region of the myostatin gene in four chicken breeds and its relationship with growth traits in the Bian chicken. Afr J Biotechnol 11 (40): 9677-82.

Zhang G, Diang F, Wang J, Dai G, Xie K, Zhang L, Wang W, Zhou S. 2011. Polymorphism in exons of the myostatin gene and its relationship with body weight traits in the Bian chicken. Biochem Genet 49: 9-19.

Zhang G, Zhang L, Wei Y, Wang J, Ding F, Dai G, Xie K. 2012. Polymorphism of the myostatin gene and its relationship with reproduction traits in the Bian chicken. Anim Biotechnol 23: 184-93. 